\title{
Effect of gibberellic acid on the seed germination of Lavandula angustifolia Mill.
}

\author{
Zs. Szekely-Varga' ${ }^{1}$ E. Kentelky ${ }^{1}$ and M. Cantor ${ }^{2 *}$ \\ 1Sapientia Hungarian University of Transylvania, Department of Horticulture, \\ Faculty of Technical and Human Sciences, Romania. \\ 2 University of Agricultural Sciences and Veterinary Medicine, Faculty of \\ Horticulture, Cluj-Napoca, Romania. \\ *Corresponding author email: marcantor@yahoo.com
}

\begin{abstract}
Lavandula angustifolia Mill. is a perennial plant, which is part of the Lamiaceae family, it is known as a medicinal and aromatic plant, however in recent years it can be found as landscaping, cut flower, or even in the art of culinary. This majestic plant propagation by seeds is a slow, hard difficult stage, for this reason, new methods are needed. Biostimulants could improve seed germination percentage and time, and also could improve productivity and growth of the plants. This study aimed at the effect of $\mathrm{GA}_{3}$ on two commercial cultivars of Lavandula angustifolia Mill. Lavender seeds were subjected to three concentrations of gibberellic acid $(100,200,300 \mathrm{ppm})$, under controlled conditions in the growing chamber. Under our experimental conditions $\mathrm{GA}_{3}$ improved the germination percentage and time of lavender seeds. It can be concluded that biostimulators, as gibberellic acid could have an effect on dormancy breaking of Lavandula seeds.
\end{abstract}

Keywords: biostimulants, dormancy, $\mathrm{GA}_{3}$, germination, lavender.

\section{INTRODUCTION}

Today there is a growing interest in the Lavandula angustifolia Mill. species industry, but it is also recognized in academia, health sciences, cosmetics as well as art. The aromatic Mediterranean plant has been known and used since ancient times (Hanamanthagouda et al., 2010; Pohrib and Nistor, 2012). Lavender is a beautiful addition to almost any garden (Berringer Bader, 2012). The Lavandula genus includes more than 45 species and about 400 of cultivars (Abdelkader et al., 2011; Koulivand et al., 2013). It is native to the Mediterranean Basin, from southern Europe to North and East Africa and countries from the Middle East to southwest Asia and southeast India (Lambardi et al., 2013; Lis-Balchin, 2017).

More and more farmers are choosing to grow this wonderful plant because it is a plant that does not require a lot of care and attention, but at the same time, it is also considered a profitable crop.

Lavender can be propagated by seeds, vegetative with cuttings of shoots, or layering. Sowing is done in greenhouses (in boxes), solarium, in March, or outside in the nursery, in May. The optimum temperature for seed germination is $18^{\circ} \mathrm{C}$, the plants sprout in $14-20$ days from sowing (Toma and Petra, 2020). 
However, the germination of Lavandula seeds is a problem in growing these plants. The germination rate depends on the quality of the seeds, their dormancy percentage, and the degree of dormancy of each seed (Chavagnat, 1977). Seed dormancy is a bottleneck for some plant species, necessary to complete germination (Bewley, 1997). Lavender propagated by generative propagation (seeds) is used more for plant breeding. Although this propagation is cheaper, it is not used much in large crops because the germination capacity is low and not uniform.

Germination biostimulators can influence germination percentage and release dormancy, the dormant state of lavender seeds (Yang et al., 2020). According to previous research seed dormancy and the growth of these seed-derived plants can be influenced by the use of hormones/growth promoters (Giannoulis et al., 2020; Jelačić et al., 2008; Liopa-Tsakalidi et al., 2011). The fruits of the lavender comprise four nodules, located at the base of the persistent calyx of brown, grayish to black color. Lavender seeds are hard, smooth, shiny and covered with a weakly permeable membrane; they, therefore, germinate slowly and over a long period. They are very small, elongated, about $1 \mathrm{~mm}$ thick and $2 \mathrm{~mm}$ long (Butnaraș, 2016; Vârban and Vârban, 2017). According to Toma and Jitareanu (2007), GA3 is one of the most used gibberellins. Gibberellin treatments can completely replace vernalization; moreover, vernalization can induce plant sensitivity to the action of gibberellins (Chouard, 1960; Levy and Dean, 1998). Brewster and Butler (1989) studied the effect of gibberellic acid $\left(\mathrm{GA}_{3}\right)$ on Allium cepa species.

Performing treatments before vernalization, the results aimed to increase the number of flowers in some genotypes studied. Also, Naamni et al., (1980) have also been performed numerous studies on the administration of gibberellic acid (spraying, immersion, injection). Doses and methods of application greatly influence the response of plants to these treatments.

Gibberellic acid $\left(\mathrm{GA}_{3}\right)$ plays a key role in releasing dormancy and promoting seed germination (Kucerna et al., 2005). $\mathrm{GA}_{3}$ is an essential biostimulator, for several plant development processes, this includes germination, plant growth, and effective induction of flowering; it significantly reduces the stratification requirement of slow germinating seed species (Kitchen and Meyer, 1991). It is also a natural regulator, which is used in agriculture and horticulture, having a considerable impact on plant growth (Cornea-Cipcigan et al., 2020; Nasri et al., 2014). Positive effects of $\mathrm{GA}_{3}$ on seed germination have been demonstrated in multiple ornamental plants (Lee et al., 2016; Urbanova and LeubnerMetzger, 2018; Nasri et al., 2014), but also in lavender seeds (Liopa-Tsakalidi et al., 2011; Singh and Srivastava, 1990; Chavagnat, 1977).

The dormancy of lavender seeds is a complicated problem at the moment, as the seeds germinate hardly and slowly. Regarding this, the experiment aimed to find new and efficient methods to increase the germination rate of Lavandula angustifolia Mill. seeds. 


\section{MATERIALS AND METHODS}

The study was conducted in 2018 at the University of Agricultural Sciences and Veterinary Medicine Cluj-Napoca the Institute for Advanced Horticultural Research of Transylvania, Romania.

We have selected two commercial lavender cultivars highly cultivated in Romania: Lavandula angustifolia 'Codreanca' approved in 1992, considered to be one of the cultivars that are very well suited to the climatic conditions in our country, being frost resistant and having a volatile oil concentration of 1.40-1.48\% (Butnaraș, 2016). On a floral stem, there are 5-6 small flowers arranged in terminal spiky inflorescences, their color is a dark blue to purple, and they give off a pleasant fragrance.

Lavandula angustifolia 'Sevtopolis' is native to Bulgaria. Of all the cultivars approved in Bulgaria, 'Sevtopolis' has the highest values for basic chemical components such as Lavandulyl acetate, Lavandulol. 'Sevtopolis' is $40-60 \mathrm{~cm}$ tall. The flowering period is in MayJuly, which requires a suitable sunny and semi-shady environment. In the above-mentioned cultivars, it has been observed that 6-7, even 8 flowers per $7 \mathrm{~cm}$ of floral stem and their color is light blue-violet to silver-blue.

In this experiment, the influence of the biostimulator $\mathrm{GA}_{3}$ (gibberellic acid) on the generative propagation of lavender was investigated. The experiment was bifactorial design with the following factors (Table 1).

Combining the two experimental factors resulted in eight experimental variants. Twenty seeds of each experimental variant were placed in each Petri dish and $\mathrm{GA}_{3}$ (gibberellic acid) was added in different concentrations, 0 ppm (Control), 100 ppm, 200 ppm, 300 ppm. For the concentrations, $1 \mathrm{mg}, 2 \mathrm{mg}$, and $3 \mathrm{mg}$ of gibberellic acid respectively were weighed and $10 \mathrm{ml}$ of distilled water was added to each. Each day seeds germinated were counted and noted.

Calculation of ppm (parts per million) concentrations:

$(\mathrm{X} \mathrm{mg} / \mathrm{Yml}) \times 1000=\mathrm{Z}$ ppm.

$(1 \mathrm{mg} / 10 \mathrm{ml}) \times 1000=100 \mathrm{ppm}$.

$(2 \mathrm{mg} / 10 \mathrm{ml}) \times 1000=200 \mathrm{ppm}$.

$(3 \mathrm{mg} / 10 \mathrm{ml}) \times 1000=300 \mathrm{ppm}$.

Germination percentages of lavender seeds were calculated according to the Timson germination rate test (Timson, 1965), modified by Khan and Ungar (1984):

$\sum \mathrm{G} / \mathrm{t}$; where $\mathrm{G}$ is the percentage of seeds that germinated after 1-day intervals and $\mathrm{t}$ is the total germination time.

GP = Seed germination/Total seeds $\times 100$ (Liopa-Tsakalidi et al., 2011; Vicente et al., 2004).

Table 1. Lavender seed germination

\begin{tabular}{|c|c|}
\hline Factor A --Cultivar with 2 graduations & Factor B - $\mathrm{GA}_{3}$ with 4 graduations \\
\hline \multirow{3}{*}{$\mathrm{a}_{1}$ - Lavandula angustifolia 'Codreanca' } & $\mathrm{b}_{1}-0 \mathrm{ppm}$ (Control) \\
\cline { 2 - 2 } & $\mathrm{b}_{2}-100 \mathrm{ppm}$ \\
\cline { 2 - 2 } & $\mathrm{b}_{3}-200 \mathrm{ppm}$ \\
\hline \multirow{3}{*}{$\mathrm{a}_{2}-$ Lavandula angustifolia 'Sevtopolis' } & $\mathrm{b}_{4}-300 \mathrm{ppm}$ \\
\cline { 2 - 2 } & $\mathrm{b}_{1}-0 \mathrm{ppm}(\mathrm{Control})$ \\
\cline { 2 - 2 } & $\mathrm{b}_{2}-100 \mathrm{ppm}$ \\
\cline { 2 - 2 } & $\mathrm{b}_{3}-200 \mathrm{ppm}$ \\
\hline
\end{tabular}


Lavender seeds were germinated in a growth chamber (EKOCHL 700), where the humidity was between $60-70 \%$ and the temperature was between $18-20^{\circ} \mathrm{C}$.

The results of the experiment were statistically analyzed using Paired Two Sample t-test for Means (<0.05), with Microsoft Excel software and post hoc comparisons were made using a Tukey HSD test.

\section{RESULTS AND DISCUSSIONS}

Seeds of the two lavender cultivars (Lavandula angustifolia 'Codreanca' and Lavandula angustifolia 'Sevtopolis') have been placed to germination with $\mathrm{GA}_{3}$ biostimulator on 20.03.2018. Within seven days, on 26.03.2018, the first seeds started germinating in Petri dishes to which gibberellic acid was added. At each concentration the number of germinated seeds was different, but in the Petri dishes for the control seeds germination only started after 11 days, on 30.03.2018 and in smaller numbers.

Observations on the germination of lavender seeds lasted 35 days and in the end differences in germination between treatments could be observed. It could also be observed visually that the lavender seeds treated with gibberellic acid were better developed and grew at a faster rate.

Gibberellic acid plays an important role in seed germination (Ritchie and Gilroy, 1998) through a multiple biostimulator mechanism (Fincher, 1989). However, the stimulatory effects of gibberellic acid on seed germination are not similar in all crop species (Bell et al., 1995). There are many reports on how gibberellic acid could influence seed germination. According to the results presented by Liopa-Tsakalidi et al., (2011) seed germination rate increased in lavender when $\mathrm{GA}_{3}$ solutions were added. A study by Chavagnat (1977), on dormancy and seed germination, showed that $\mathrm{GA}_{3}$ favorably influenced seed germination when applied at the dose of $200 \mathrm{ppm}$. Other studies carried out by Janowska and Stanecka (2011), confirm the effectiveness on leaf longevity when preserving Zantedeschia treated with $\mathrm{GA}_{3}$ solution with a high concentration of $400 \mathrm{mg} / \mathrm{l}$.

Gibberellic acid had an increased number of the germinated seeds in both lavender cultivars, compared to control (Figure 1 and 2). However, seed germination was treatment dependent, seeds under the effect of $\mathrm{GA}_{3}$ had an increased number of germinations, and also the under the treatment it was recorded quicker germination.

First seeds germinated were observed at the $\mathrm{GA}_{3}$ treatments, which were recorded after 7 days, on contrary, the lavender seed in the control treatment started germinating after 11 days.

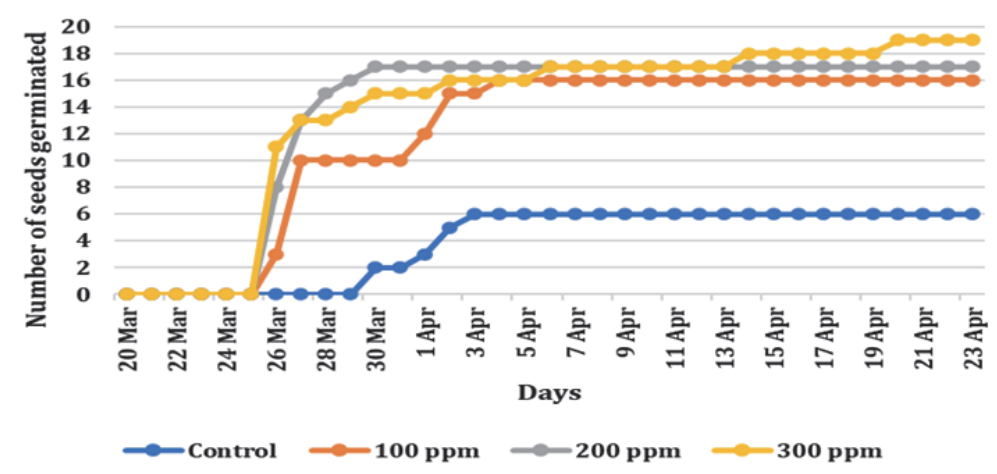

Figure 1. Number of seeds germinated at 'Codreanca' cultivar 


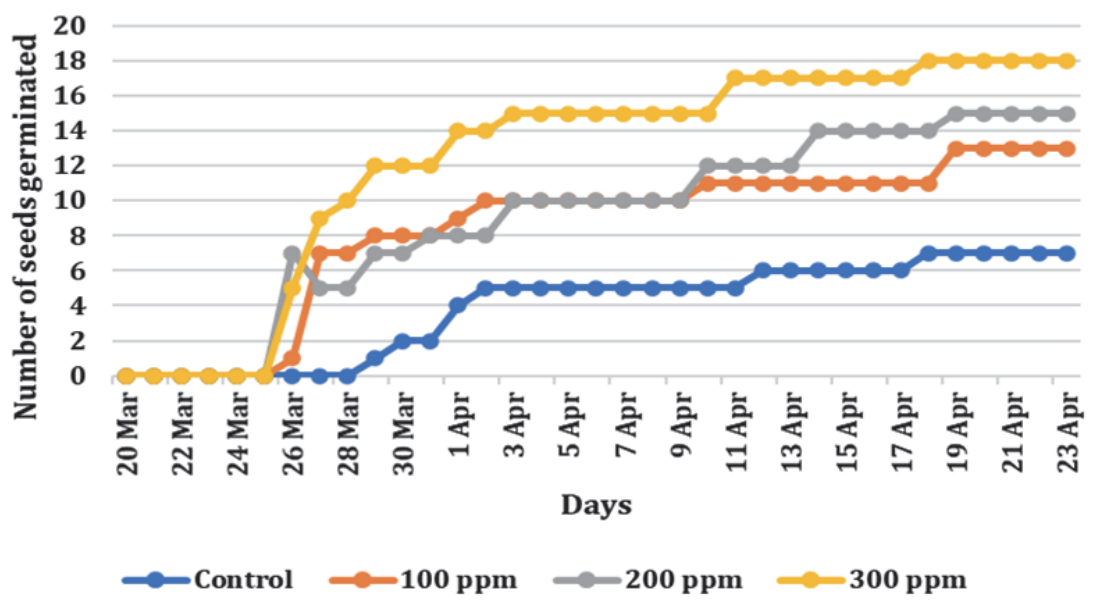

Figure 2. Number of seeds germinated at 'Sevtopolis' cultivar

Analysing Figure 3 and 4 it can be observed that the highest germination percentage in both cultivars it was recorded at the 300ppm treatment (Figure 5d) of gibberellic acid. In the cultivar 'Codreanca' the germination percentage reaches $95 \%$ and, in the cultivar, 'Sevtopolis' the germination percentage was $90 \%$.

The seeds under $200 \mathrm{ppm} \mathrm{GA}$ treatment (Figure 5c) reported an increased germination percentage followed by the $\mathrm{GA}_{3} 100 \mathrm{ppm}$ treatment (Figure 5b). Thus, at $\mathrm{GA}_{3} 200 \mathrm{ppm}$ treatment the 'Codreanca' cultivar reached a germination percentage of $85 \%$ and the 'Sevtopolis' cultivar 75\%, and at 100 ppm gibberellic acid treatment the Romanian cultivar 'Codreanca' had a germination percentage of $80 \%$ and the Bulgarian cultivar 'Sevtopolis' a germination percentage of $65 \%$. In contrast the lavender seeds in the control treatment (Figure 5a) had a much lower germination percentage, in 'Codreanca' only $30 \%$ and in 'Sevtopolis' 35\%.

Similar results were obtained by Roșca et al., (2016) in Allium 'Purple Rain', who reported that with increasing $\mathrm{GA}_{3}$ concentrations up to $500 \mathrm{ppm}$ the best germination increases were observed.

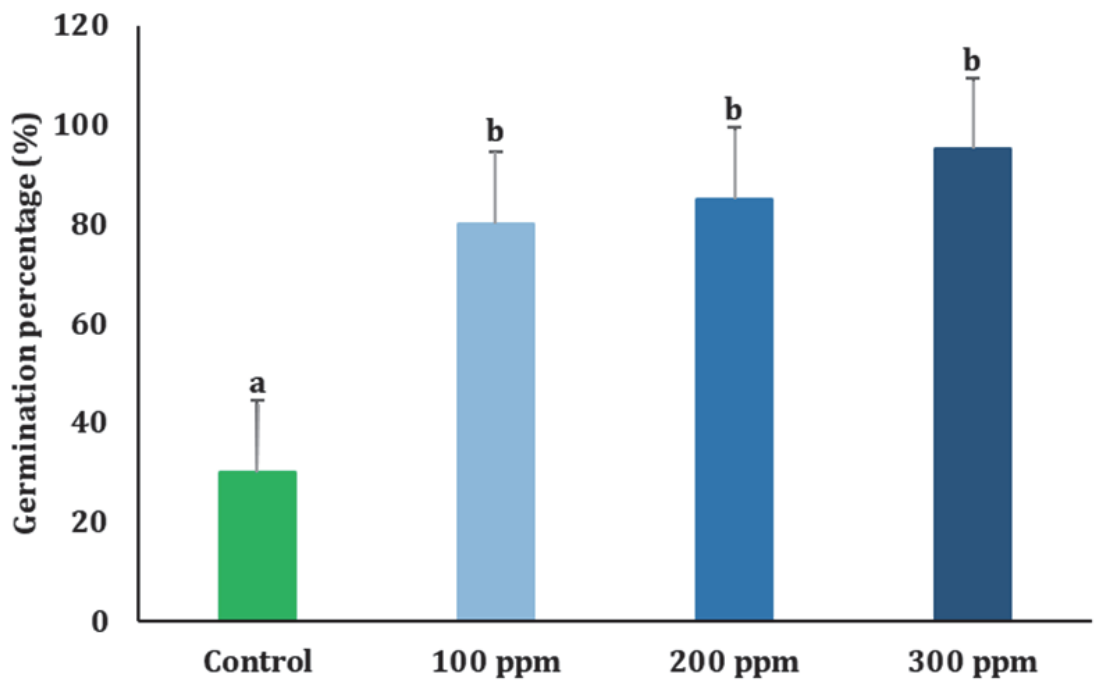

Figure 3. Germination percentage at 'Codreanca' cultivar 


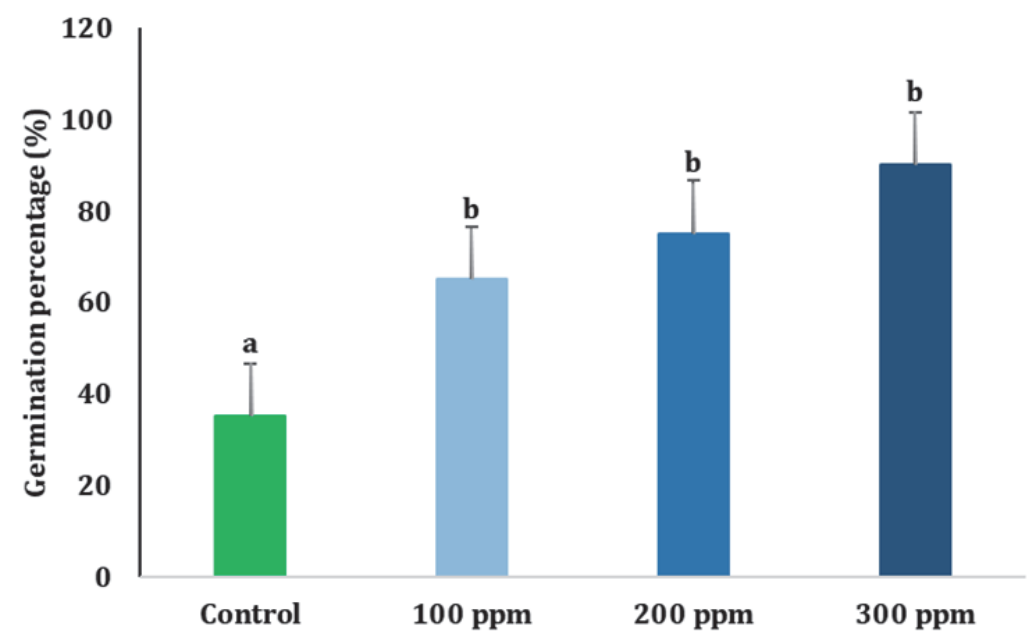

Figure 4. Germination percentage at 'Sevtopolis' cultivar

Cornea-Cipcigan et al., (2020) has experimented to evaluate the influence of gibberellic acid $(50,100$, or $150 \mathrm{mg} / \mathrm{L})$, on the germination earliness of seeds, along with the growth and ornamental quality of selected Cyclamen species. They were found a significant difference in germination percentage (GP), mean germination time (MGT) and seedling vigor index (SVI), within different $\mathrm{GA}_{3}$ supplementation and greenhouse sunlight intensity (short and long days).

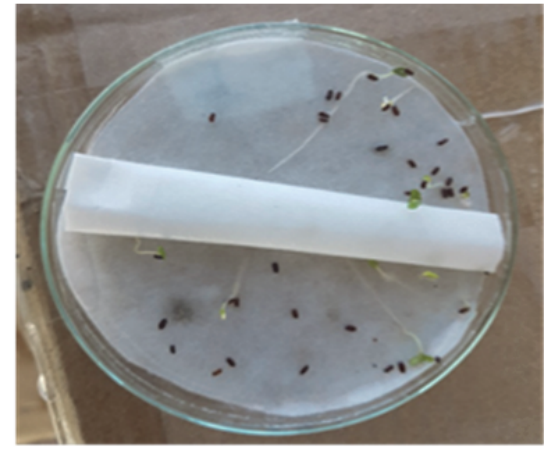

(a)

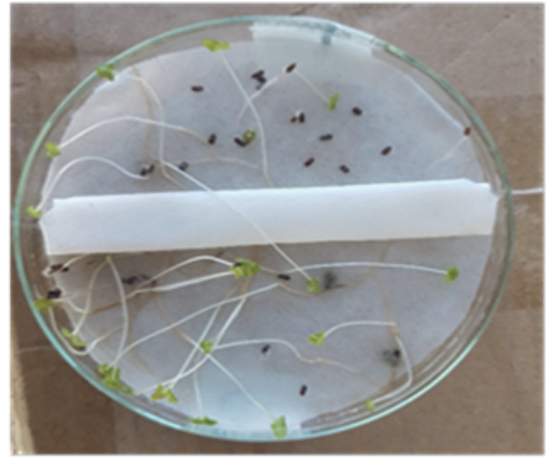

(c)

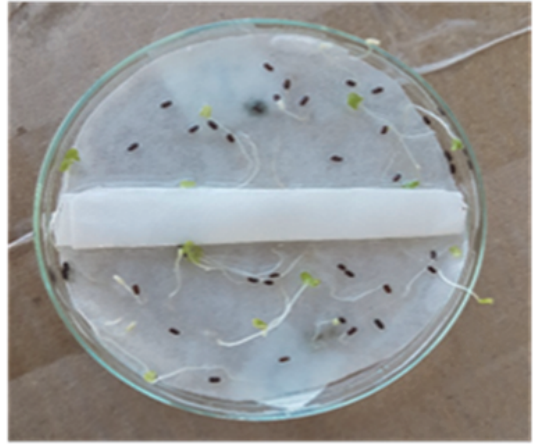

(b)

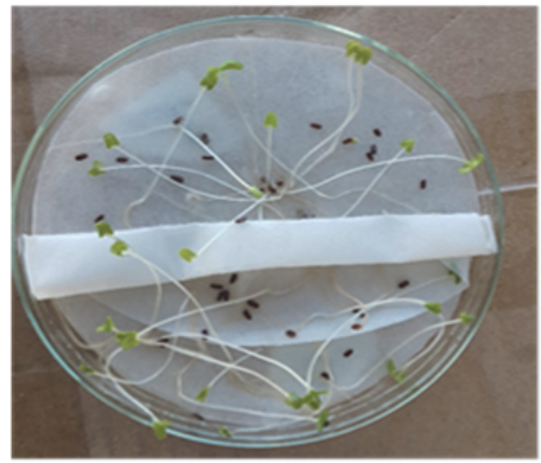

(d)

Figure 5. Seed germination of Lavandula angustifolia 'Codreanca' and 'Sevtopolis';

a-Control; b-100 ppm; c-200 ppm; d-300 ppm 


\section{CONCLUSIONS}

From the present study can be concluded that lavender seeds under the effect of $\mathrm{GA}_{3}$ at high concentrations above $100 \mathrm{ppm}$ resulted in higher germination percentages than untreated variants in both Lavandula angustifolia cultivars. Thus, was observed that $\mathrm{GA}_{3}$ treatment reported a germination percentage of $80-95 \%$ at 'Codreanca' and $65-90 \%$ at 'Sevtopolis' (depending on the treatment), compared to $35 \%$ and $30 \%$ in the untreated variants (control). Due to the high germination percentage, we can state that the dormancy, the resting state of the seeds was positively influenced by $\mathrm{GA}_{3}$. However, the excess of $\mathrm{GA}_{3}$ can also negatively influence plant growth, as plants develop and grow at a higher rate, which can lead to quicker mortality.

\section{REFERENCES}

1. Abdelkader, T.B., Zitouni, A., Guitton, Y., Jullien, F., Maitre, D., Casabianca, H. and Kameli, A. (2011). Essential oils from wild populations of Algerian Lavandula stoechas L.: composition, chemical variability, and in vitro biological properties. Chemistry \& biodiversity, 8(5), 937-953.

2. Bell, D.T., Rokich, D.P., McChesney, C.J. and Plummer, J.A. (1995), Effects of temperature, light and gibberellic acid on the germination of seeds of 43 species native to Western Australia. Journal of Vegetation Science, 6(6), 797-806.

3. Berringer Bader, S. (2012). The lavender lover's handbook. Timber Press, London.

4. Bewley, J.D. (1997). Seed germination and dormancy. Plant Cell, 9, 1055-1066.

5. Brewster, J.L. and Butler H.A. (1989). Inducing flowering in growing plants of overwintered onions; effects of supplementary irradiation, photoperiod, nitrogen, growing medium and gibberellins. Journal of Horticultural Science, vol. 64 (3), 301-312.

6. Butnaraș, V. (2016). Crearea şi evaluarea hibrizilor policross de Lavandula angustifolia. Academia de Științe a Moldovei, Institutul de genetică, fiziologie și protecția plantelor, Chișinău.

7. Chavagnat, A. (1977). Lavender seed dormancy and germination. In Symposium on Seed Problems Horticulture, 83, 147-154.

8. Chouard, P. (1960). Vernalization and its relation to dormancy. Annual Revue of Plant Physiology, vol. 11, p. 191-238.

9. Cornea-Cipcigan, M., Pamfil, D., Sisea, C.R. and Mărgăoan, R. (2020). Gibberellic acid can Improve seed germination and ornamental quality of selected Cyclamen species grown under short and long days. Agronomy, 4, 516.

10. Fincher, G.B. (1989). Molecular and cellular biology associated with endosperm mobilization in germinating cereal grains. Annual review of plant biology, 40(1), 305-346.

11. Giannoulis, K.D., Evangelopoulos V., Gougoulias N. and Wogiatzi E. (2020). Could bio-stimulators affect flower, essential oil yield, and its composition in organic lavender (Lavandula angustifolia) cultivation? Industrial Crops and Products, 154, 112611.

12. Hanamanthagouda, M.S.; Kakkalameli, S.B.; Naik, P.M.; Nagella, P.; Seetharamareddy, H.R.; Murthy, H.N. (2010). Essential oils of Lavandula bipinnata and their antimicrobial activities, Food Chemistry, 118(3), 836-839.

13. Janowska, B. and Stanecka, A. (2011). Effect of growth regulators on the postharvest longevity of cut flowers and leaves of the calla lily (Zantedeschia Spreng.). Acta Agrobotanica, 64(4), 91-98.

14. Jelačić, S., Kišgeci, J., Beatović, D., Moravčević, Đ. and Bjelić, V. (2008). The use of biostimulators and slow decomposing fertilizer with different ways of Lavender seedlings production. In Proceedings of the Fifth Conference on Medicinal and Aromatic Plants of Southeast European Countries, (5th CMAPSEEC), Brno, Czech Republic, 2-5 September, 2008.

15. Khan, M.A. and Ungar, I.A. (1984). The effect of salinity and temperatures on the germination of polymorphic seeds and growth of Atriplex triangularis Willd. American Journal of Botany, 71, 481-489.

16. Kitchen, S.G. and Meyer, S.E. (1991). Seed germination of Intermountain penstemons as influenced by stratification and GA3 treatments. Journal of Environmental Horticulture, 9(1), 51-56.

17. Koulivand, P.H., Khaleghi Ghadiri M. and Gorji A. (2013). Lavender and the nervous system, Evidence-Based Complementary and Alternative Medicine.

18. Kucerna, B., Cohn, M.A. and Leubnermetzger, G. (2005). Plant hormone interactions during seed dormancy release and germination. Seed Science Research, 15, 281-307.

19. Lambardi, M., Ozudogru, E.A. and Jain, S.M. (2013). Protocols for micropropagation of selected economicallyimportant horticultural plants. Hertfordshire: Humana Press. 
20. Lee, J.W., Kim, Y.C., Kim, J.U., Jo, I.H., Kim, K.H. and Kim, D.H. (2016) Effects of gibberellic acid and alternating temperature on breaking seed dormancy of Panax ginseng CA Meyer. Korean Journal of Medicinal Crop Science, 4, 284-293.

21. Levy, Y.Y., and Dean, C. (1998). The Transition to Flowering. The Plant Cell, vol. 10, 1973-1989.

22. Liopa-Tsakalidi, A., Zakynthinos, G., Varzakas, T. and Xynias, I.N. (2011). Effect of NaCl and GA 3 on seed germination and seedling growth of eleven medicinal and aromatic crops. Journal of Medicinal Plants Research, 5(17), 4065-4073.

23. Lis-Balchin, M. (2017). Lavender, Handbook of Herbs and Spices. Woodhead Publishing Ltd \& CRC Press, Vol. 2.

24. Naamni, F., Rabinowitch, H.D. and Kedar, N., (1980). The effect of GA3 Application on Flowering and Seed Production in Onion. Journal of the American Society for Horticultural Science 105 (2), 164-167.

25. Nasri, F., Khosheh Saba, M., Ghaderi, A., Akbar Mozafari A. and Javadi, T. (2014). Improving germination and dormancy breaking in Alstromeria ligtu hybrid seeds. TJS 1, 38-46.

26. Pohrib, E.L. and Nistor, E. (2012). Spikes of azure bloom: lavender-history and stories. Scientific Papers, Series A. Agronomy, 55, 397-405.

27. Ritchie, S. and Gilroy, S. (1998). Gibberellins: regulating genes and germination. The New Phytologist, 140(3), 363-383.

28. Roșca, A.E., Draghia, L., Chelariu, L.E. and Brînza, M. (2016). Studies regarding the bioregulators influence over the morphologic and ornamental characters of Allium" Purple Rain". Lucrări științifice USAMV Iasi, Seria Horticulture, 59, 2, 325-330.

29. Singh, J.M., and Srivastava, I.J. (1990). Seed germination in lavender with acid treatment. Seed Research, 18, 86-87.

30. Timson, J. (1965). New method of recording germination data. Nature, 207, 216-217.

31. Toma, F. and Petra, S. (2020). Floriculture and floral compositions. Editure Total Publishing Bucharest, 282283.

32. Toma, L.D. and Jităreanu, C.D. (2007). Plant Physiology (Fiziologie vegetală). Editure Ion Ionescu de la Brad, Iasi, 262-265.

33. Urbanova, T. and Leubner-Metzger, G. (2018). Gibberellins and seed germination. Annual Plant Reviews, 49, 253-284.

34. Vârban R. and Vârban D.I. (2017). Plante medicinale cultivate și din flora spontană, Bioflux. Cluj-Napoca, 5660.

35. Vicente, O., Boscaiu, M., Naranjo, M. Á., Estrelles, E., Bellés, J. M. and Soriano, P. (2004). Responses to salt stress in the halophyte Plantago crassifolia (Plantaginaceae). Journal of Arid Environments, 58(4), 463481.

36. Yang, L.E., Peng, D.L., Li, Z.M., Huang, L., Yang, J. and Sun, H. (2020). Cold stratification, temperature, light, GA3, and $\mathrm{KNO}_{3}$ effects on seed germination of Primula beesiana from Yunnan, China. Plant Diversity, 42(3), 168-173. 